\title{
Copper, Zinc, Selenium, Cadmium and Lead Levels in plasma of Hemodialysis Patients.
}

\author{
Shawkia S. A. El-Sherbeny ${ }^{*}$, Asmaa, M. Abd Allah" ${ }^{* *}$, Waleed Massoud ${ }^{* * *}$ \\ *Nutritional Biochemistry Department. National Nutrition Institute. \\ ${ }^{* * *}$ Clinical Nutrition Department. National Nutrition Institute. \\ **** Nephropathy Department-Ahmed Maher Teaching Hospital.
}

\begin{abstract}
Introduction: Hemodialysis patients are at risk of developing trace elements imbalance and increase in heavy metals. Objective: The objective of this study was to asses plasma levels of copper, zinc, selenium, cadmium and lead of hemodialysis patients. Design: The study comprised 40 patients aged 27-65 years under regular hemodialysis for 1.8-13 years and 28 healthy age and sex matched the control. Copper, zinc, selenium, cadmium and lead plasma levels were determined by atomic absorption spectrophotometry. Results: Levels of copper, zinc and selenium were significantly decreased in dialysis patients compared with the control group; the percentage decrease was $25.5 \%, 20.4 \%$ and $19.0 \%$ for copper zinc and selenium, respectively. Moreover, cadmium and lead plasma levels showed significant increases among hemodialysis patients versus their matched controls with percentage of $144.6 \%$ and $28.1 \%$ for cadmium and lead, respectively. Conclusions: Levels of trace elements are altered and heavy metals showed increased plasma levels by hemodialysis. Regular monitoring of trace elements and heavy metals in hemodialytic patients is advisable.
\end{abstract}

Keywords: Hemodialysis, Copper, Zinc, Selenium, Cadmium, Lead.

\section{Introduction:}

Altered blood and tissue concentrations of trace elements have been described in patients with chronic renal failure treated by hemodialysis (HD) (Berlyne, 1995). The most important factors for this alteration are the degree of renal failure and the modality of renal replacement therapy (Vanholder et al., 1996).

Copper $(\mathrm{Cu})$ is an important element for hemoglobin synthesis, connective tissue metabolism and bone development (Brody, 1994). Copper may play a role in the antioxidant defene system such as copper/zinc superoxide dismutase ( $\mathrm{Cu} / \mathrm{ZnSOD})$, ceruloplasmin and intracellular thioneins. (Linder, 1996). Serum copper tends to be generally low in patients treated with HD
(Lee et al., 2000). Suspected copper deficiency was also supposed to play a role in the pathogenesis of anemia and growth retardation of dialyzed patients. (D'Haese and De Broe, 1996).

Zinc $(\mathrm{Zn})$ is an essential trace element; it is used by a great number of enzymes, such as alkaline phosphates, superoxide dismutase, protein kinase $\mathrm{C}$ and carboxypeptidase A, B (Brody, 1994). Serum and plasma zinc in HD patients were found either to be normal (Agenet et al., 1989) or more often decreased (Cabral et al., 2005). Zinc depletion was suggested to play a role in the pathogenesis of some uremic symptoms, e.g. impotence (testicular atrophy), immunological impairment, 
growth retardation, abnormalities of taste (dysgeusia, anorexia) and olfaction (Zima et al., 1999).

Selenium (Se) is an essential trace element with several important roles in the human body: synthesis of thyroid hormones; role in antioxidant mechanisms, as an essential component of the antioxidant enzyme glutathione peroxidase; production of prostaglandins and promotion of growth and fertility (Brody, 1994). Selenium is probably decreased in plasma, erythrocytes and white cells of dialyzed patients (Mestek et al., 2002). Selenium deficiency has been implicated as contributing to the development of cardiovascular disease (congestive cardio-myopathy), accelerated atherosclerosis, skeletal muscle myopathy, anemia, infertility and deranged immune function (Zima et al., 1999). Almost all these problems are common in patients with renal failure.

Cadmium $(\mathrm{Cd})$ is toxic and lead to growth retardation, impairment reproduction, hypertension, cancer and also decreased zinc, copper and calcium absorption in the gastrointestinal tract (Linder, 1991). Serum levels of cadmium in patients with chronic renal failure were reported to be normal (Malecka et al., 1994)), high (Turan et al., 1992)) or even decreased (Thomson et al., 1983). The whole blood cadmium levels were increased in HD patients (Hsu et al., 1997).

Accumulation of lead $(\mathrm{Pb})$ has been reported in patients with renal failure. In a study conducted by Staessen et al. (1992), on a random population of 965 men and 1016 women, the creatinine clearance was found to be inversely correlated with blood lead values. Furthermore, a 10-fold increase in blood lead was associated with a 10-13 $\mathrm{ml} / \mathrm{min}$ reduction in creatinine clearance. Thus, the hypothesis that renal impairment resulted in blood lead accumulation could not be ruled out. In Egypt, as nutritional awarness is iasufficient and environmental pollution is high, hemodialysis patients are at risk of developing imblavced trace element levels. The present study was carried out to determine the concentration of copper, zinc, selenium, cadmium and lead in plasma of hemodialysis Egyptian patients

\section{Subjects and methods:}

Forty patients with end stage renal failure undergoing regular hemodialysis were recruited from the outpatient's dialysis unit of Ahmed Maher teaching hospital, Cairo, Egypt, during the period from November 2004 to March 2005. All patients were on bicarbonate-dialysis with cellulose for duration of 1.8-13 years (4.5 \pm 2.4$)$. Their characteristics is illustrated in table (1). The control group comprised 28 age and sex matched healthy persons. Informed consent was obtained from all the participants. Patients were not taken any constituent drug including copper, zinc or selenium.

Fasting (12 hours) venous blood samples were collected from patients (before dialysis) and controls in heparinzed tubes. The plasma was separated by centrifugation. Plasma levels of copper, zinc, selenium. Cadmium and lead were determined according to AOAC (1990), using AAS Vario 6 atomic absorption spectrometer.

\section{Statistical analysis:}

The data were subjected to statistical analysis using computer programme SPSS (1996). Independent $t$-test and one-way analysis of variance (ANOVA) were used, the difference was considered significant at p-value< 0.05 (Zar, 1984).

\section{Results:}

The HD patients had significantly lower plasma levels of copper (25.5\%), zinc $(20.5 \%)$ and selenium $(19.0 \%)$ than the healthy control group (table 2).

The mean plasma levels of copper, zinc and selenium of HD patients were within the normal values. However, 5 $(12.5 \%), 8(20 \%)$ and $11(27.5 \%)$ patients were classified as copper, zinc and selenium deficient, respectively.

With regard to the measured heavy metals, both cadmium and lead (table 3) were significantly elevated in HD patients as compared with the control group; the percentage increase was $144.6 \%$ and $28 \%$ for cadmium and lead, respectively. 
Table (1): Characteristics of Hemodialysis Patients.

\begin{tabular}{|l|c|}
\hline \multicolumn{1}{|c|}{ Variable } & \\
\hline Age (mean \pm SE) & $49.5 \pm 11.3$ years \\
\hline Sex: Males & $24(60 \%)$ \\
Females & $16(40 \%)$ \\
\hline Dialysis time (hours/session) & 6 hours \\
\hline Kt/v (mean \pm SE) & $1.12 \pm 0.23$ \\
\hline Causes of renal disease: & \\
Hypertensive nephropathy & $16(40 \%)$ \\
Diabetic nephropathy & $8(20 \%)$ \\
Pyelonephritis & $4(10 \%)$ \\
Renal stones & $410 \%)$ \\
Polycystic kidney & $2(5 \%)$ \\
Hyperthyroidism & $1(2.5 \%)$ \\
Unknown causes. & $5(12.5 \%)$ \\
\hline
\end{tabular}

Table (2): Plasma levels of copper, zinc and selenium of the HD patients and control. $($ Mean \pm S.D)

\begin{tabular}{|c|c|c|c|}
\hline parameters & $\begin{array}{c}\text { HD patients } \\
(\mathrm{n}=40)\end{array}$ & $\begin{array}{c}\text { Control } \\
(\mathrm{n}=28)\end{array}$ & $\%$ change \\
\hline $\begin{array}{c}\text { Plasma copper }(\mathrm{NV}=80- \\
140 \mathrm{ug} / \mathrm{dl})\end{array}$ & $99.195 \pm 28.30^{*}$ & $133.066 \pm 27.94$ & $-25.5 \%$ \\
\hline $\begin{array}{c}\text { Plasma zinc }(\mathrm{NV}=70-140 \\
\mathrm{ug} / \mathrm{dl})\end{array}$ & $98.123 \pm 13.20^{*}$ & $123.233 \pm 23.15$ & $-20.4 \%$ \\
\hline $\begin{array}{c}\text { Plasma selenium (NV=6- } \\
17 \mathrm{ug} / \mathrm{dl})\end{array}$ & $7.427 \pm 1.87^{*}$ & $9.171 \pm 1.87$ & $-19.0 \%$ \\
\hline
\end{tabular}

* Significant at $\mathrm{P}<0.05$

$\mathrm{NV}=$ Normal value. (Versiek and Cornetis, 1980)

Table (3): Plasma levels of cadmium and lead of the HD patients and control. (Mean \pm S.D)

\begin{tabular}{|c|c|c|c|}
\hline parameters & $\begin{array}{c}\text { HD patients } \\
(\mathrm{n}=40)\end{array}$ & $\begin{array}{c}\text { Control } \\
(\mathrm{n}=28)\end{array}$ & \% change \\
\hline $\begin{array}{c}\text { Plasma cadmium (NV=0- } \\
2 \mathrm{ug} / \mathrm{l})\end{array}$ & $0.592 \pm 0.179^{*}$ & $0.242 \pm 0.092$ & +144.6 \\
\hline $\begin{array}{c}\text { Plasma Lead (NV=0.8-2.5 } \\
\mathrm{ug} / \mathrm{l})\end{array}$ & $1.237 \pm 0.399^{*}$ & $0.965 \pm 0.281$ & +28.2 \\
\hline
\end{tabular}

* Significant at $\mathrm{P}<0.05$

NV= Normal value (Versiek and Cornetis, 1980).

\section{Discussion:}

Plasma levels of copper were found significantly lower in dialysis patients compared with normal controls. These results are in keeping with a number of studies reporting lower copper plasma concentrations in hemodialysis-treated patients (Lee et al., 2000 and Weissgarten et al., 2001). .On the other hand, high (Hsieh et al., 2006) or normal plasma levels of copper (Berger et al., 2004) have been reported. Decreased plasma copper may in some dialyzed patients correlate with erythrocyte superoxide dismutase activity (Vandecateele et al., 1993). However, 
Weissgarten et al. (2001) found that plasma ceruloplasmin levels as well as ceruloplasmin-bound copper fraction were significantly lower in HD patient compared with normal subjects, and that the free copper fraction was significantly higher in this patient group. This would tend to suggest that ceruloplasmin capacity to bind copper was decreased in uremic plasma.

Previuos reports have indicated a significant decrease in plasma zinc concentration in hemodialysis patients as compared with healthy controls (Cabral et al., 2005 ; Hsieh et al., 2006). The result of the present study agreed with these findings. However, in another study, zinc levels were found to be normal in HD patients (Agenet et al., 1989).

The observed decreased plasma zinc levels in HD patients may be connected with low zinc intake, dietary restriction in association with augmented zinc excretion which may be caused by either decreased zinc absorption or increased its excretion or both by gut ( Kimmel et al., 1988 ; Mahajan et al., 1989). Moerover, affinity of zinc to albumin in uremic patients was found to be decreased (Foote and Hinks, 1988). However, the decreased serum zinc concentration found in HD patients may be related to a redestribution of zinc in the tissues and not to its true deficiency because in most studies reporting a reduction in serum zinc levels, the concentration in red blood cells is elevated (Peuchant et al., 1994).

In this study, selenium level was significantly lower in $\mathrm{HD}$ patients than control group. Similar results have been reported in previous studies (Yavuz et al., 2004 ; Hsieh et al., 2006 ). These findings seemed to be justifiable because in human among other organs, the kidney contains the highest level of selenium (Zachara et al., 2001a) and plays an important regulatory role in homeostasis of the element (Robinson et al., 1985). Glutathione peroxidase is a selenium dependent glycosylated enzyme synthesized primarilty in the proximal tubular cells of the kidney (Avissar et al., 1994). Decreased activity of this enzyme has been detected in red blood cells and plasma of chronic renal failure patients
(Zachara et al., 2000\& 2001b). Renal failure itself may have some influence on selenium concentration probably through decreased absorption in the small intestine (Bonomini et al., 1996). Moreover, a low dialysate concentration of selenium may result in its removale during HD with resulting in deficiency (D'Haese et al., 1996).

The trace elements status in chronic renal failure patients may also be influenced by residual renal function, the dialyzer membrane and size, the nature of the water used for preparation of dialysate, the method of purification and the composition of dialysis concentrate (Gault et al., 1991). Efficient water purification processes and ultra-low dialysate levels of a number of trace elements may lead to a deficiency in some essential elements (D'Haese et al., 1996). However, Padovese et al. (1992) found that the concentration of copper, zinc and selenium in HD dialysate were low and suggested that these elements should be considered more carefully in studies determining the profiles in body fluids and tissues of uremic patients undergoing regular dialysis treatment.

With regard to heavy metals, Plasma cadmium levels of HD patients were significantly higher than healthy control. This results agreed with other reports (Turan et al., 1992 \& Lee et al., 2000). Furthermore, increased tissue concentration of cadmium in the liver and spleen and decreased concentrations in the kidneys were detected in HD patients (Smythe et al., 1982).

The source of cadmium in HD patient are currently unknown, but environmental factors such as cosmetics containing heavy metals, polluted water and air may be involved (Klein et al., 1972 \& Sondheimer et al., 1988). In healthy individual, normal functioning kidneys eliminate toxic elements from the body. However, in renal failure, declining kidney functions leads to an accumulation of potentially nephrotoxic elements which may contribute to the deterioration of renal function (Vanholder et al., 1996).

Many investigators have described increased levels of lead in renal failure 
patients (D'Haese et al., 1999 ; Kim et al., 2006). The results of the present study are consistent with these reports. The kidney is the main organ excreting lead from pool. Thus, lead burdens have a tendency to be accumulated in the patients with renal failure (Silbergeld et al., 1988). In patients with end stage renal disease, hyperparathyroidism, abnormal vitamin D metabolism, and consequent osteoporosis have frequently been observed (Llach and Bover, 2000). Taken together with the lack of renal excretion and stimulated bone resorption, may confirm the increased blood levels of lead in patients with end stage renal disease. Major forms of lead poisoning are colic, hypertension, and neuropathy. It is not easy to define these symptoms in patients with end stage renal disease because uremia itself may cause of and/or aggravate these symptoms. Furthermore, chronic lead poisoning may be a cause of end stage renal disease (Thun et al., 1982).

However, increased heavy metals concentrations in renal failure patients can result from excessive homeopathic intake, industrial or environmental exposure, and inhalation of cigarette smoke, administration of parental fluids or blood contact with contaminated dialysate (Vanholder et al., 1996).

In conclusion; levels of trace elements are altered and heavy metals showed increased plasma levels by hemodialysis. Regular monitoring of trace elements and heavy metals in hemodialytic patients is advisable.

\section{Recommendation}

Further investigation on large scale on Egyptian hemodialysis patients should be carried out to assess the real situation of these elements

\section{References:}

1. Agenet C., Brugere C.C. and Reynier J.P. (1989): Concentrations de cuivre et de zinc plasmatiques et intra-erythrocytaires les sujets urémiques traités par hemodialyse périodique. Ann. Biol. Clin. 47: 493-496

2. AOAC (1990): Official Methods of Analysis, $5^{\text {th }}$ edn. Wilson Baulevard Arligton (edn.) The Association of Official Analytical Chemists. Inc. Arlington, Vergnia, USA.

3. Avissar N, Ornt D B, Yagil Y, et al. (1994): Human kidney proximal tubules are the main source of plasma glutathione peroxidase. Am. J. Physiol. 266:

4. Berger M M, Shenkin A, Revelly J P., Roberts E, Cayeux M C, Baines $M$ and Chiléro R. L. (2004): Copper, selenium, zinc and thiamine balances during continuous venovenous hemodifilteration in critical ill patients. Am. J. Clin. Nutr. 80:410-416.

5. Berlyne G G (1995): Trace metal burden in uremia. In: Mzssery, S.G, Glassock, RJ. EDS. Textbook of Nephrology. Baltimore: Williams \&Wilkins, pp 1459-1495.

6. Bonomini M, Foster S, Manfrini V, De Risio F, Stiner M, Vidovich $M \quad J$, Klinkmann H, Ivanovich $P$. and Albertazzi A. (1996): Geographic factors and plasma selenium in uremia and dialysis. Nephron., 72: 197-204.

7. Brody T. (1994): Nutritional biochemistry, London, Academic Press, pp: 581-595; 597-609.

8. Cabral P C, Diniz A D S and De Arruda I K J (2005): Vitamin A and zinc status in patients on maintenance haemodialysis. Nephrology ., 10: 459-463.

9. D'Haese P C and De Broe M E (1996): Adequacy of dialysis: Trace elements dialysis fluids. Nephrol. Dial. Transplant 11(suppl2): 92-97.

10. D'Haese $\mathbf{P}$ C, Couttenye $\mathbf{M}$ M, Lamberts L V et al. (1999): Aluminum, iron, lead, cadmium, copper, zinc, chromium, magnesium, strontium and calcium in bone of end-stage renal failure patients. Clin. Chem., 45: 1548-1556.

11. Foote $\mathbf{J} \mathbf{W}$ and Hinks $\mathbf{L} \mathbf{J}$ (1988): Zinc absorption in hemodialysis patients. Ann. Clin. Biochem. 25: 398-402.

12. Gault $M \mathbf{H}$, Longerich, $L$, Longerich $H$ (1991): Trace elements and hemodialysis. Nephron., 58: 498-499.

13. Hsieh y, Shin W, Lee $L$, Wu T, Ning $H$ and Sun $T$ (2006): Long-term changes in trace elements in patients undergoing chronic hemodialysis. Biol. Trav. Elem. Res., 109: 115-121. 
14. Hsu W A, Lee K C, Lin S L, Lee S H, Hcieh S J, Kan Y T, Yang C S, Wu D. J, Chen P Y, Chen J S and Chen W Y (1997): Clinical manifest-ations of trace metals abnormality in hemodialysis patients: A multicenter collaborative study, Dial. Transplant., 26: 15-20.

15. Kim Y S, Park J H, Hong J R, Gil H W, Yang J O, Lee E Y and Hong S Y (2006): Influence of blood lead concentration on the nerve conduction velocity in patients with end-stage renal disease. J Korean Med Sci., 21(2): 290-294.

16. Kimmel P L, Bowersz D H, Teller E B, Khanna $R$ Dosa $S$ and Phillips $\mathbf{T}$ M (1988): Zinc balance in a combined zinc defieciency and uremia. Kidney Int., 33: 1091-1099.

17. Klein W J, Metz $\mathbf{E} \mathbf{N}$ and Price A R (1972): Acute copper intoxication) A hazard of hemodialysis. Arch. Intern. Med., 129: 578-582.

18. Lee S, Huang J, Hung K, Leu L, Kan Y, Yang C, Wu D, Huang C, Chen P, Chen $J$ and Chen W (2000): Trace metals' abnormalities in hemodialysis patients: Relationship with medications. Artif. Organ., 24(1): 841-844.

19. Linder M G (1991): Nutrition and Metabolism of the Trace Elements, In Linder (ed): Nutritional Biochemistry and Metabolism with Clinical Application, ed 2. Englewood Cliffs, Prerentic-Hall., pp 215276.

20. Linder M G (1996): Copper; in Ziegler E.E. Jiler L.J. Jr (eds.): Present Knowledge in Nutrition, ed 7. Wasgington, ILSI Press., pp: 307-319

21. Llach, $\mathbf{F}$ and Bover, J (2000): Renal osteodystrophies. In: Brenner and Rector's The Kidney, Brenner BM, ed. W.B Saunders Co., 2103-66.

22. Mahajan S K, Bowersox E M , Rye D L, Abu-hamdan D K, Prasa A S McDonaldm F D and Biersack K L (1989): Factors underlying abnormal zinc metabolism in uremia. Kidney Int., 36 (suppl 27): 269-273.

23. Malecka J, Grzeszczak W, ZukowskaSzczechowska W and Baczynski R (1994): Levels of cadmium in serum of patients with chronic renal failure. (in Polish). Przegl. Lek., 51: 291-295.

24. Mestek O, Kominkova J, Koplik R, Zima T, Miskusova $M$ and Stem $P$ (2002): Specification of $\mathrm{Cu}, \mathrm{Se}, \mathrm{Zn}$ and $\mathrm{Fe}$ in blood serum of hemodialysis patients. Sb. Lekarsky., 103 (1): 23-27

25. Padovese $\mathbf{P}$, Gaillieni M, Brancaaccio D, Pietra R, Fortaner S, Sabbioni E, Minoia C, Markakis $K$ and Berlin A (1992): Trace elements in dialysis fluid and assessment of regular hemodialysis, hemofilteration and continuous ambulatory peritoneal dialysis. Nephron., 61: 442-448.

26. Peuchant E, Carbonneau M A, Duourg L. et al. (1994): Lipoperoxidaton of plama and red blood cells of patients undergoing hemodialysis. Free Radiol. Biol. Med., 16: 339-346.

27. Robinson J R, Robinson M F, Lavander O.A., et al. (1985): Urinary excretion of selenium by New Zealand and North American human subjects on different intakes. Am. J. Clin, Nutr. 41:1023-1031.

28. Silbergeld E K, Schwartz J, Mahaffey K. (1988): Lead and osteoporosis: mobilization of lead from bone in postmenopausal women. Environ Res., 47: 79-94.

29. Smythe W R, Alfrey A C , Craswell P W, Crouch C A, Ibels L S, Kibo H, Nunnelley L L and Rudolph H (1982): Trace elements ubnormalities in chronic uremia. Ann. Inter. Med., 96: 302-310.

30. Sondheimer J H., Mahajan S.K., Rye D.L, Abu-Hamdan D.K., Migdal S.D., Prasad A.S. and McDonalad F.D. (1988): Elevated plasma copper in chronic renal failure. Am. J. Clin. Nutr., 47: 869879.

31. SPSS (1996): Staistical package for social science computer soft ware version 8 (USA) on an IBM, PC Computer Bailey (1994).

32. Staessen J A, Lauwerys R R, Buchet J $P$, et al. (1992): Impairment of renal function with increasing blood lead concentrations in the general population. $\mathrm{N}$. Engl. J. Med., 327: 151-156.

33. Thomson N M , Stevens B J, Humphrey T J and Atkins R C (1983): Comparison of trace elements in peritoneal dialysis, hemodialysis and uremia. Kidney Int., 23: 9-14.

34. Thun M, Stayner L., Brown D. and Waxweiler R. (1982): Mining and deaths from chronic renal failure. Lancet., 2: 606.

35. Turan B, Delilbasi E, Dalay N, Sert S, Afrasyap L and Sayal A (1992): Serum selenium and glutathione peroxidase activities and their interaction with toxic 
metals in dialysis and renal transplantation patients. Biol. Trace Elem. Res. 33: 95102

36. Vandecateele $\mathbf{C}$, Vanhoe $\mathbf{H}$ and Dams $\mathbf{R}$ (1993): Inductively coupled plasma mass spectrometry of biological samples. J. Anal. Atom. Spectrom., 8: 781-786.

37. Vanholder R, Cornelis R, Rhondt $A$ and Ringoir S (1996): Trace elements metabolism in renal disease. In Kopple, J., Massry, S.G.eds. Nutritional Management of Renal Disease. Wilkins, Baltimore. pp 395-414.

38. Versieck I and Cornetis $R$ (1980): Normal levels of trace elements in human blood plasma or serum. Anal. Chem. Acta., 116: 217-254.

39. Weissgarten J, Berman S, Bilchinsky R, Modai $D$ and Averbukh $Z$ (2001): Total Cell-Associated $\mathrm{Zn}$ and $\mathrm{Cu}$ and Proliferative responsiveness of Peripheral Blood Mononuclear Cells From Patients on Chronic Hemodialysis. Metabolism, 50 (3): 270-276.

40. Yavuz O, Bicik Z, Cinar Y, Guney Y and Guler S (2004): The effect of different dialysis memberanes on oxidative stress and selenium status. Clin. Chem. Acta., 364 (2): 153-160.

41. Zachara B A, Adamowicz A, Trafikowska et al. (2000): Decreased plasma glutathione peroxidase activity in uremic patients. Nephron .,84: 278-279.

42. Zachara B A, Pawluk E, BlochBogustawska E, et al. (2001a): Tisuue level distribution and total body selenium content in healthy humans and in some diseases in Poland. Arch. Environ. Health., 56: 461-465.

43. Zachara B A, Trafikowska U, Adamowicz A. et al. (2001b): Selenium, glutathione peroxidase and some other antioxidant parameters in blood of patients with chronic renal failure. J. Trace. Elements Med. Biol., 15: 161-166.

44. Zar J H (1984): Biostatistical analysis. $2^{\text {th }}$ edn. Prencice-Hall, Englewood Cliffs, N.J. pp. 196-198.

45. Zima T, Tesar V, Mestek $O$ and Nemecek K (1999): Trace elements in end-stage renal disease. Blood Purif., 17: 187-198 


\section{تركيز النحاس و الزنك و السيلينيوم و الكادميوم و الرصاص فى بلازما مرضى

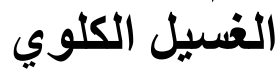

\section{شوقية سيد عبد الحليم الثربينى 1 ، أسماء محمود عبد اللةّ2 ، وليد مسعود 3} 1 -قسم كيمياء التغذية- المعهد القومي للتغذية.2- قسم التخذية الإكلينيكية ـ المعهد القومي

\section{للتغذية.}

3- قسم الكلى- مستشفى أحمد ماهر التعليمي.

مقدمة: يتعرض مرضى الغسيل الكلوي لخطر عدم توازن العناصر الدقيقة و

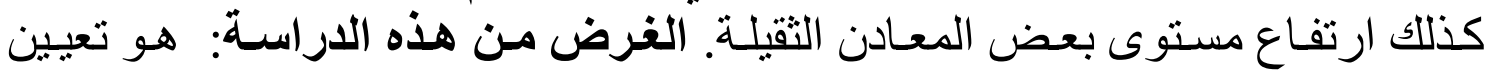

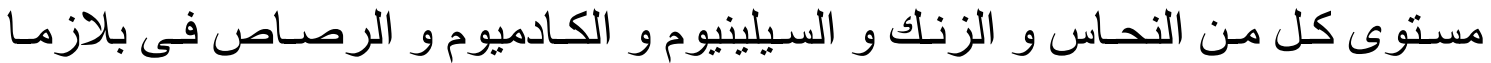

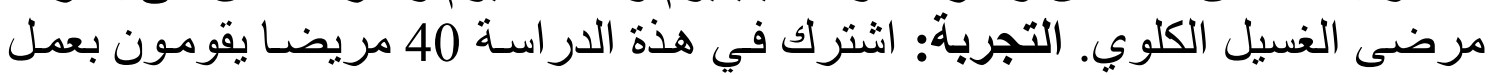

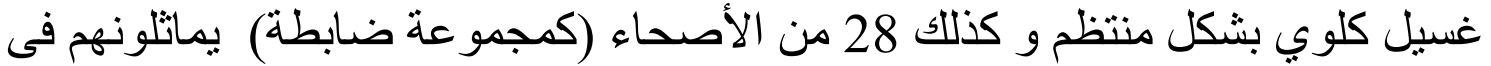

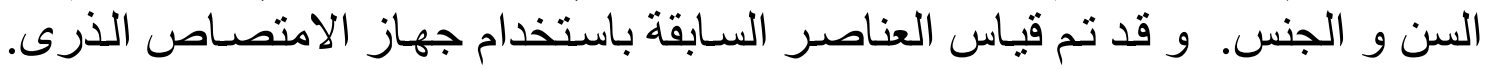

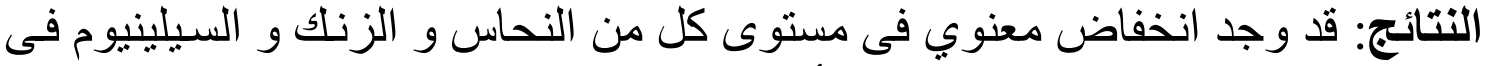

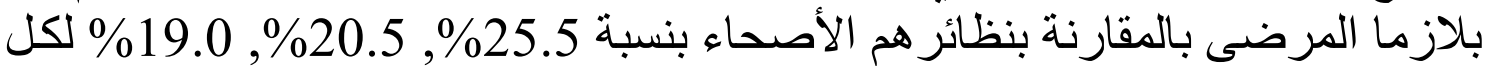

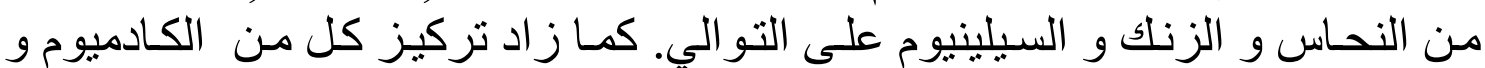

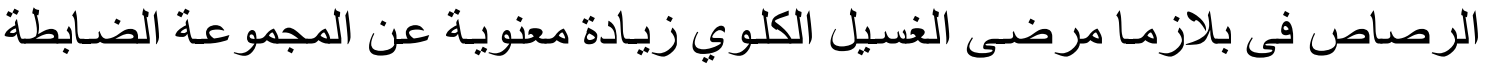

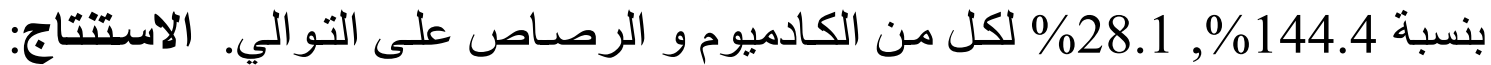

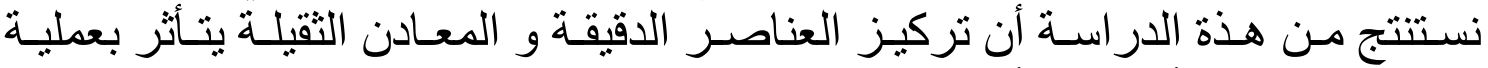
الغسيل الكلوي و أنه يجب أن يتم تقدير هذه العناصر لهؤلاء المرضى بشكل منتظم. 